\title{
Patient perceptions on the subject of medical research
}

\author{
This article was published in the following Dove Press journal: \\ Drug, Healthcare and Patient Safety \\ 17 October 2014 \\ Number of times this article has been viewed
}

\author{
Gary Ventolini' \\ Breanna Goodwin' \\ Courtney Woody ${ }^{2}$ \\ 'School of Medicine, ${ }^{2}$ Texas Tech \\ University Health Sciences Center, \\ Odessa, TX, USA
}

\begin{abstract}
While performing medical research we often spend little time addressing patient's views on how research participants perceive the trial will affect their own condition. This manuscript identifies various ways in which the field of medicine must approach the important subject of patient's outlook. The described approach is vital to succeed at achieving meaningful patient's involvement in research.
\end{abstract}

Keywords: human, trials, involvement, insights, options

\section{Introduction}

Given new developments in patient access to care and health information, in addition to greater patient interest in the research process, the practice of medicine and the patientphysician relationship have changed. However, the inclusion of the patient experience within the realm of research has lagged behind this development. Due to this advancement, the field of medicine must once again update its approach; within this paper are identified various manners in which the field must address its changing ethical duties.

\section{History of research ethics}

Since the introduction of research ethics, the medical establishment has attempted, with varying degrees of success and some infamous failures, to operate within an understanding of protecting human research subjects. Although diminishing human suffering was internationally codified in 1964 and Institutional Review Boards (IRBs) were defined in 1974, concepts like autonomy, beneficence, and justice were just defined as national research ethics in $1979 .{ }^{1}$ Our discussions on ethics in the American medical arena are still rife with issues: for example, the 2008 President's Council on Bioethics failed to agree on a universal definition of "dignity". The council was unsuccessful in addressing how to protect human dignity, which was considered a medical duty in the 1964 Declaration of Helsinki. ${ }^{2}$ Even more basic for a field dedicated to the protection of the patient, our ethical practice rarely engages the perspectives of patients involved in research, despite the fact that patients are essential constituents for conducting said research. Furthermore, clinicians are not sufficiently educated to consider all of the perceptions patients suffering from chronic conditions may have toward research.

\section{Patient responses to medical conditions}

Given the finite number of therapeutic possibilities, patient reactions toward their specific chronic conditions are limited; the same is true for drug research trials in that patients 
choices in research are threefold: 1) decline to participate; 2) passively participate in the proposed clinical trial, whether for their own benefit of for the "greater good"; or 3) actively participate as an "expert" patient, that is, a patient who researches, knows, and understands almost everything regarding his/her medical condition.

With the advent of recent technological advances, social media interaction, and accessible internet search engines, more and more curious and thoughtful patients have decided to increase their knowledge and understanding of their specific medical condition, becoming "expert patients". This expertise can also be achieved through interactions with other patients affected by the same medical condition or through an advocacy health association. When these patients have both resources and empowerment, they also possess a combination of incomplete and often unrelated material, other patients' anecdotes, and their personal experience as reliable sources of medical information. Often the patient has not obtained information from the most accurate and up-to-date sources, causing misperception, misunderstanding, and mistrust that could compromise the patient-physician relationship. ${ }^{3}$ As patient involvement in his or her own care is crucial and frequently beneficial, it is of growing importance that physicians are able to encourage patient self-education in appropriate and accurate ways.

Many of these expert patients become involved in patient associations dedicated to empowering patients and fighting for disease visibility. However, these patient-empowered associations are not accounted for in our research system. They have no dedicated voice in our IRBs. We have no active roles in patient management or representation. How do we conscionably uphold that we are working for the benefit of the patient if we do not allow space for their voices? And what happens when active patients want their voices to be heard?

Some seek legal recourse. Current "Right to Try" bills in Colorado, Louisiana, Arizona, and Missouri attempt to circumvent Food and Drug Administration (FDA) standards by asserting a right to try any available treatment, even if it may prove harmful to humans. As evidenced by these bills, the time frame of the patient is not equal to that of the researcher. Patients have a pressing need for intervention and are anticipating that research will provide them with the benefit their specific condition often urgently requires. The popularity of these bills may demonstrate the willingness of patients and patient associations to become involved in the research process at all levels.

This proposed legislation also demonstrates the difficulty of reacting to clinical uncertainty. Even when the diagnosis is unclear, physicians still have the duty to treat their patients by establishing a tentative diagnosis. On the other hand, when the diagnosis is certain but the treatment offered is risky and its side effects and outcome are uncertain, the physician cannot wait to act but in acting, still must adhere to "primum non nocere (first, do no harm)". Therefore, since only imperfect information is available, the clinical judgment and decision making is usually done by comparing the normative model established by the statistical decision theory. ${ }^{4}$

Lastly, there is real concern related to the involvement of patients in clinical research based on computerized models, which utilize probabilistic approaches as opposed to real scenarios. One example is the use of Bayes' Theorem to calculate the probability of a patient having a condition after each visit, and/or a "one-shot" approach, which computes the probability of a patient having a condition, based on hospital or outpatient billing diagnosis. ${ }^{5}$

The caution principle states that the physician should abstain from intervening when in doubt; however, the research principle states that the physician must carry out the experiment to be able to answer the doubts. How can these two principles be coherent?

\section{Patient expectations}

IRBs serve as the main protectors of human research participants. Despite this, many IRBs are lacking staff and resources to carry out this task. ${ }^{1}$ As several IRBs lack the support to carry out their role of monitoring an ongoing study, auditing and quality assurance programs, if implemented, can serve as a preventative measurement. IRBs have also been shown to vary widely on how they interpret and apply regulations concerning consent forms and conflicts of interest, as well as their review of protocols. ${ }^{2}$ To prevent conflicts of interest, the independence and integrity of IRBs should be secured.

Table I Patient expectations of the research field

\begin{tabular}{|c|c|}
\hline $\begin{array}{l}\text { Only those interventions that are } \\
\text { strictly necessary to complete the } \\
\text { study are proposed, nothing more }\end{array}$ & $\begin{array}{l}\text { The role of the patient association } \\
\text { is to assist in the recruitment of } \\
\text { patients to the study, and they } \\
\text { have no hidden agendas }\end{array}$ \\
\hline $\begin{array}{l}\text { The sponsor of the study } \\
\text { and the principal investigator } \\
\text { are two different persons }\end{array}$ & $\begin{array}{l}\text { Researchers have a meaningful } \\
\text { desire to conduct the research, } \\
\text { apart from economic drivers or } \\
\text { personal achievement }\end{array}$ \\
\hline $\begin{array}{l}\text { Among the IRB, powers have } \\
\text { been equally distributed between } \\
\text { physicians, researches, and patient } \\
\text { representatives }\end{array}$ & $\begin{array}{l}\text { The trial will make a real, } \\
\text { innovative, and tangible impact } \\
\text { upon the research field, not } \\
\text { create another equal but more } \\
\text { expensive alternative }\end{array}$ \\
\hline
\end{tabular}

Abbreviation: IRB, Institutional Review Board. 
Accreditation of IRBs may be an effective approach to improving quality of research and human subject protection. ${ }^{1}$

In Table 1, we identify areas we could address within research to better account for the experiences, voices, and expectations of the patient. We feel that transparency within our IRB system can be improved by better balancing power as well as by attributing some powers to individuals who represent only the patients and not the research. Updating our research system in this way can advance our research ethics by creating greater focus upon the patient.

\section{Conclusion}

Within our profession, we need to be focused upon the benefits and risks facing a patient, and on their inherent rights of autonomy and justice - truly, we have the duty to protect the wellbeing of the human person.

Our research ethics continue to develop, and we are in search of transparency, clarifications, and practical clinical applications. But within this ethical research, within this sphere of human "protection", where do we account for the experience of the patient?

\section{Disclosure}

The authors report no conflicts of interest in this work.

\section{References}

1. Bankert E, Cooper JA. History and Ethical Principles. Miami, FL: Collaborative Institutional Training Initiative. Available from: https:// www.citiprogram.org. Accessed September 27, 2012.

2. World Medical Association. Declaration of Helsinki: Ethical Principles for Medical Research Involving Human Subjects. New York, NY: World Medical Association; 1964. Available from: http://www.wma.net/ en/30publications/10policies/b3/. Accessed June 13, 2014.

3. Ahmad F, Hudak PL, Bercovitz K, Hollenberg E, Levinson W. Are physicians ready for patients with Internet-based health information? J Med Internet Res. 2006;8(3):e22.

4. Myers RB, Herskovic JR. Probabilistic techniques for obtaining accurate patient counts in Clinical Data Warehouses. J Biomed Inform. 2011; 44 Suppl 1:S69-S77.

5. Elstein AS. Heuristics and biases: selected errors in clinical reasoning. Acad Med. 1999;74(7):791-794.
Drug, Healthcare and Patient Safety

\section{Publish your work in this journal}

Drug, Healthcare and Patient Safety is an international, peer-reviewed open-access journal exploring patient safety issues in the healthcare continuum from diagnostic and screening interventions through to treatment, drug therapy and surgery. The journal is characterized by the rapid reporting of reviews, original research, clinical, epidemiological and

\section{Dovepress}

post-marketing surveillance studies, risk management, health literacy and educational programs across all areas of healthcare delivery. The manuscript management system is completely online and includes a very quick and fair peer-review system. Visit http://www.dovepress.com/ testimonials.php to read real quotes from published authors. 